\title{
Implementation of content analysis in assessment of business attractiveness of regions of Volga Federal district.
}

\author{
Irina Glebova \\ Kazan Federal University, Institute of Management, \\ Economics and Finance, \\ Department of public and municipal administration \\ Kazan, Russia \\ gle-irina@yandex.ru
}

\author{
Andrey Vorobyev \\ Kazan Federal University, Institute of Management, \\ Economics and Finance, \\ Department of public and municipal administration \\ Kazan, Russia \\ andrew_russia@mail.ru
}

\author{
Victoria Svishcheva \\ Kazan Federal University, Institute of Management, \\ Economics and Finance, \\ Department of public and municipal administration \\ Kazan, Russia \\ svishevav@mail.ru
}

\begin{abstract}
This paper contains the description of a method which assesses business attractiveness of a region based on the content analysis of the analytical publications. The analysis resulted in the qualitative assessment of the business environment and revealed issues that impede further development of small and middle-sized businesses in certain regions.
\end{abstract}

Keywords - attractiveness, content analysis, business environment, qualitative assessment, business, entrepreneurship, small and middle size businesses (SMB).

\section{INTRODUCTION}

Business attractiveness is a set of necessary conditions to attract small and middle size businesses and facilitate their development in a region affecting its economic and social development. Proper support of SMB has an influence on the majority of key indicators of regional social and economic development such as the employment rate, gross regional product, the income level of the population, tax revenues of the region, retail trade turnover etc. Objective realities of wellfunctioning economies of developed countries identify the need for accurate and timely assessments of the indicators listed above. One of the realities is a structural refocusing towards the private sector, in particular, creation of favorable environment for development of SMB. Rising competition among regions for investment flows to the sector of SMB created high demand in the leverage power for regions in enhancing its business attractiveness. Thus, assessment and creation of favorable business climate becomes a relevant issue in both theoretical and practical aspects.

\section{THE STATUS OF THE ISSUE}

According to the data from the Federal Statistics Service (Rosstat), as of 2016, the share of small and middle size businesses in the GDP is $20 \%$. However, this share is significantly larger in developed countries. Thus, the creation of supportive investment climate and substantial improvements in conditions of business attractiveness in order to increase the flow of businesses become the strategic goals of all regions of the Russian Federation.

That is why, various conditions and perspectives of business attractiveness are offered by regions enabling them to compete for it. The main goal is to attract the maximum number of influential businesses. They exploit resources and potential of the region as well as take advantages of instruments in the economy and politics. Regions have to reap their full potential effectively to attract and retain businesses.

\section{LITERATURE REVIEW}

Business attractiveness is a key element of building the market economy. That is why, so many authors (C. JeanPierre [1], N. Marzieh, V. Thierry [2], S. Samik [3]) refer to this definition in their papers. However, proper study of business attractiveness should cover a number of aspects. I. Lock, P. Seele [4], E. Khan, M. Quaddus [5] consider business attractiveness through the assessment of business environment by the mean of content analysis. Conducted research in the field of theoretical aspects of content analysis for the assessment of business attractiveness can be found in the studies of L. Hadas, A. Stachowiak, P. Cyplik [6].

The main issue is the lack of consensus with respect to assessment methodology of business attractiveness due to the 
sharp differences in institutional conditions of regions. However, it is generally agreed that the results of assessments can serve as a key indicator of regional development, provided it was applied in accordance with the proper assessment methodology. Limited awareness in the field of business attractiveness research can hinder possibilities of intensive development of SMB due to the research of J. Belas, P. Bartos, J. Habanik [7] and R. Sadyrtdinov, M. Korablev, S. Vladimirova [8].

\section{RESEARCH METHODOLOGY}

Business attractiveness of the Republic of Tatarstan, Samara region and Saratov region were analyzed as research subjects.

The following research implements content analysis for the authoritative analysis of the federal business magazines, which consider issues of business attractiveness of the above listed regions.

The content analysis was conducted on the basis of 4 publications on the business attractiveness of the Republic of Tatarstan, Samara region and Saratov region from 2014 to 2016. The number of characters is issued as a unit of count. The following publications act as sources of content analysis:

1. "Kommersant Daily Newspaper" - Russian daily newspaper covering social and political fields with the focus on the business sector. The newspaper is the key source of business and political news in the Russian information space.

2. "Forbes Russia" - the news portal on economics and business.

3. "RBK daily" - the leading internet source of daily analytical information on business issues with the target audience of business people.

4. Business newspaper "Vzglyad" - the news portal aimed at timely publication of newsworthy events in business.

The following characteristics of the Republic of Tatarstan were issued as semantic units:

- Business support

- Barriers for business

- Business problems

- Business ranking

- Labor market

- Business competition

- Tax burden

- Business loans

- Technology parks/ Business incubators

- Solvency of the population

- Protection of entrepreneurs' rights

\section{EMPIRICAL RESEARCH: KEY RESULTS}

Results of the conducted content analysis of the regions based on the 4 publications are set out in the summary tables. The summary table of the results of content analysis of business attractiveness of the Republic of Tatarstan is provided below as an example.

TABLE I. SUMMARY TABLE OF THE RESULTS OF CONTENT ANALYSIS OF BUSINESS ATTRACTIVENESS OF THE REPUBLIC OF TATARSTAN (THE RT) IN 2016.

\begin{tabular}{|l|c|c|c|c|c|}
\hline \multicolumn{1}{|c|}{ Characteristic } & Positive & Neutral & Negative & In total & \% \\
\hline $\begin{array}{l}\text { Business attractiveness } \\
\text { of the RT }\end{array}$ & 38264 & 3683 & 11687 & 53634 & 9.4087 \\
\hline $\begin{array}{l}\text { Business support in the } \\
\text { RT }\end{array}$ & 71333 & 17080 & 16910 & 105323 & $\mathbf{1 8 . 4 8}$ \\
\hline $\begin{array}{l}\text { Barriers for business in } \\
\text { the RT }\end{array}$ & 12679 & 4527 & 43313 & 60519 & 10.617 \\
\hline $\begin{array}{l}\text { Business problems in } \\
\text { the RT }\end{array}$ & 53936 & 3241 & 38394 & 95571 & $\mathbf{1 6 . 7 6 6}$ \\
\hline $\begin{array}{l}\text { Business ranking of the } \\
\text { RT }\end{array}$ & 35928 & 3269 & 18253 & 57450 & $\mathbf{1 0 . 0 8}$ \\
\hline $\begin{array}{l}\text { Labor market of the RT } \\
\text { In total }\end{array}$ & 13924 & 5150 & 11823 & 30897 & 5.42 \\
\hline $\begin{array}{l}\text { Business competition in } \\
\text { the RT }\end{array}$ & 12169 & 6226 & 8202 & 26597 & 4.6658 \\
\hline Tax burden in the RT & 2531 & 1085 & 9155 & 12771 & 2.2404 \\
\hline $\begin{array}{l}\text { Business loans in the } \\
\text { RT }\end{array}$ & 43655 & 9026 & 37176 & 89857 & $\mathbf{1 5 . 7 6}$ \\
\hline $\begin{array}{l}\text { Technology Parks/ } \\
\text { Business incubators of } \\
\text { the RT }\end{array}$ & 34856 & 2569 & 0 & 37425 & 6.5653 \\
\hline $\begin{array}{l}\text { Solvency of the } \\
\text { population of the RT }\end{array}$ & 11376 & 8083 & 13755 & 33214 & 5.8266 \\
\hline $\begin{array}{l}\text { Protection of } \\
\text { entrepreneurs' rights in } \\
\text { the RT }\end{array}$ & 0 & 2589 & 18642 & 21231 & 3.7244 \\
\hline & $\mathbf{5 5 8 5 6}$ & $\mathbf{1 9 4 9 1 3}$ & $\mathbf{5 7 0 0 4 4}$ & 100 \\
\hline
\end{tabular}

The results of the content analysis in 2016 are the following: the number of positive rating has risen from $49 \%$ to $56 \%$ as evidenced by results of table 2 . Characteristics such as barriers for business, tax burden, solvency of the population and protection of entrepreneurs' rights obtained the highest number of adverse assessments.

TABLE II. THE COEFFICIENT FACTOR OF POSITIVE ASSESSMENTS FROM 2014 TO 2016 IN THE REPUBLIC OF TATARSTAN.

\begin{tabular}{|c|c|c|c|c|}
\hline & 2014 & 2015 & 2016 & In total \\
\hline $\begin{array}{c}\text { Number of } \\
\text { characters }\end{array}$ & 264144 & 279369 & 319275 & 862788 \\
\hline$\%$ & $\mathbf{3 0 . 6 1 4 6 4 7}$ & $\mathbf{3 2 . 3 7 9 8 4 8}$ & $\mathbf{3 7 . 0 0 5 5 0 5}$ & 100 \\
\hline
\end{tabular}

The adverse assessment of perception of business environment development on the Republic of Tatarstan in 2013 and 2014 constituted $39 \%$ and $44 \%$ of the studied publications correspondingly. In 2016, the result was at the level of $34 \%$.

A relatively small upcoming trend in the business environment development was observed due to the similar analysis conducted for Samara region. 
TABLE III

SUMMARY TABLE OF THE RESULTS OF CONTENT ANALYSIS OF BUSINESS ATTRACTIVENESS OF SAMARA REGION (SMRR) IN 2016.

\begin{tabular}{|l|c|c|c|c|c|}
\hline \multicolumn{1}{|c|}{ Characteristic } & Positive & Neutral & Negative & In total & \% \\
\hline $\begin{array}{l}\text { Business attractiveness } \\
\text { of SMRr }\end{array}$ & 28402 & 5008 & 33218 & 66628 & $\mathbf{1 0 . 6 9}$ \\
\hline $\begin{array}{l}\text { Business support in } \\
\text { SMRr }\end{array}$ & 57621 & 11485 & 25419 & 94525 & $\mathbf{1 5 . 1 7}$ \\
\hline $\begin{array}{l}\text { Barriers for business in } \\
\text { SMRr }\end{array}$ & 0 & 13451 & 24569 & 38020 & 6.102 \\
\hline $\begin{array}{l}\text { Business problems in } \\
\text { SMRr }\end{array}$ & 45326 & 9715 & 99541 & 154582 & $\mathbf{2 4 . 8 1}$ \\
\hline $\begin{array}{l}\text { Business ranking of } \\
\text { SMRr }\end{array}$ & 24569 & 0 & 49562 & 74131 & $\mathbf{1 1 . 8 9}$ \\
\hline Labor market of SMRr & 4523 & 10251 & 15497 & 30271 & 4.85 \\
\hline $\begin{array}{l}\text { Business competition in } \\
\text { SMRr }\end{array}$ & 4341 & 6254 & 11225 & 21820 & 3.50 \\
\hline Tax burden in SMRr & 7164 & 5124 & 18426 & 30714 & 4.93 \\
\hline Business loans in SMRr & 34765 & 5875 & 17657 & 58297 & $\mathbf{9 . 3 5}$ \\
\hline $\begin{array}{l}\text { Technology Parks/ } \\
\text { Business incubators of } \\
\text { SMRr }\end{array}$ & 31231 & 5203 & 4532 & 40966 & 6.57 \\
\hline $\begin{array}{l}\text { Solvency of the } \\
\text { population of SMRr }\end{array}$ & 456 & 4580 & 5643 & 10679 & 1.71 \\
\hline $\begin{array}{l}\text { Protection of } \\
\text { entrepreneurs' rights in } \\
\text { SMRr }\end{array}$ & 2354 & 0 & 0 & 2354 & 0.37 \\
\hline In total & $\mathbf{2 4 0 7 5 2}$ & $\mathbf{7 6 9 4 6}$ & $\mathbf{3 0 5 2 8 9}$ & $\mathbf{6 2 2 9 8 7}$ & 100 \\
\hline
\end{tabular}

In comparison with 2015, the number of adverse assessments in Samara region decreased in 2016. However, key issues, such as barriers for business, high business competition, tax burden of the region, remain influential.

TABLE IV

THE COEFFICIENT FACTOR OF POSITIVE ASSESSMENTS FROM 2014 TO 2016 IN SAMARA REGION.

\begin{tabular}{|c|c|c|c|c|}
\hline & 2014 & 2015 & 2016 & In total \\
\hline Number of characters & 280463 & 19510 & 240752 & 716323 \\
\hline$\%$ & $\mathbf{3 9 . 1 5 3 1 5 9}$ & $\mathbf{2 7 . 2 3 7 4 2 2}$ & $\mathbf{3 3 . 6 0 9 4 1 9}$ & 100 \\
\hline
\end{tabular}

Business attractiveness in Samara region in 2014 constituted $36 \%$, in $2015-28 \%$ and in $2016-38 \%$. Adverse assessments in 2014 constituted $53 \%$ in $2014,60 \%$ in 2015 and $49 \%$ in 2016.

The rise of positive assessments of the development of business environment of Samara region is noticeable. The trend demonstrates the rise in the level of business attractiveness of the region (Table 4).

TABLE $V . \quad$ SUMMARY TABLE OF THE RESULTS OF CONTENT ANALYSIS OF BUSINESS ATTRACTIVENESS OF THE SARATOV REGION (SRTR) IN 2016.

\begin{tabular}{|l|c|c|c|c|c|}
\hline \multicolumn{1}{|c|}{ Characteristic } & Positive & Neutral & Negative & In total & \% \\
\hline $\begin{array}{l}\text { Business } \\
\text { attractiveness of SRTr }\end{array}$ & 9834 & 0 & 41234 & 51068 & $\mathbf{1 2 . 2 5}$ \\
\hline $\begin{array}{l}\text { Business support in } \\
\text { SRTr }\end{array}$ & 1930 & 5498 & 18651 & 26079 & $\mathbf{6 . 2 5}$ \\
\hline $\begin{array}{l}\text { Barriers for business } \\
\text { in SRTr }\end{array}$ & 897 & 0 & 0 & 897 & 0.21 \\
\hline $\begin{array}{l}\text { Business problems in } \\
\text { SRTr }\end{array}$ & 0 & 9659 & 129848 & 139507 & $\mathbf{3 3 . 4 6}$ \\
\hline $\begin{array}{l}\text { Business ranking of } \\
\text { SRTr }\end{array}$ & 10371 & 0 & 39836 & 50207 & $\mathbf{1 2 . 0 4}$ \\
\hline
\end{tabular}

\begin{tabular}{|l|c|c|c|c|c|}
\hline Labor market of SRTr & 2765 & 7937 & 19681 & 30383 & 7.28 \\
\hline $\begin{array}{l}\text { Business competition } \\
\text { in SRTr }\end{array}$ & 1034 & 871 & 3811 & 5716 & 1.37 \\
\hline Tax burden in SRTr & 5410 & 7413 & 13082 & 25905 & 6.21 \\
\hline $\begin{array}{l}\text { Business loans in } \\
\text { SRTr }\end{array}$ & 9540 & 11606 & 17999 & 39145 & $\mathbf{9 . 3 9}$ \\
\hline $\begin{array}{l}\text { Technology Parks/ } \\
\text { Business incubators of } \\
\text { SRTr }\end{array}$ & 15320 & 6432 & 4519 & 26271 & 6.30 \\
$\begin{array}{l}\text { Solvency of the } \\
\text { population of SRTr }\end{array}$ & 873 & 2276 & 6983 & 10132 & 2.43 \\
\hline $\begin{array}{l}\text { Protection of } \\
\text { entrepreneurs' rights } \\
\text { in SRtr }\end{array}$ & 1030 & 3095 & 7439 & 11564 & 2.77 \\
\hline \multicolumn{1}{|c|}{ In total } & $\mathbf{5 9 0 0 4}$ & $\mathbf{5 4 7 8 7}$ & $\mathbf{3 0 3 0 8 3}$ & $\mathbf{4 1 6 8 7 4}$ & 100 \\
\hline
\end{tabular}

The analysis of Saratov region demonstrates existing adverse assessment towards the development of business environment of the region and is proven by the following results: $60 \%$ - in 2014, 72\% - in 2015 and 68\% - in 2016.

TABLE VI.

THE COEFFICIENT FACTOR OF POSITIVE ASSESSMENTS FROM 2014 TO 2016 IN SARATOV REGION.

\begin{tabular}{|c|c|c|c|c|}
\hline & 2014 & 2015 & 2016 & In total \\
\hline Number of characters & 47340 & 53331 & 59004 & 159676 \\
\hline$\%$ & $\mathbf{2 9 . 6 4 8 5 6 1}$ & $\mathbf{3 3 . 3 9 9 3 2 2}$ & $\mathbf{3 6 . 9 5 2 1 1 7}$ & 100 \\
\hline
\end{tabular}

On the other hand, the percent of positive assessments has risen in Saratov region from 14\% in 2014 to $16 \%$ in 2015 and to $18 \%$ - in 2016.

According to the conducted content analysis, business attractiveness of the Republic of Tatarstan, Samara region and Saratov region demonstrated an upcoming trend in 2016 in comparison with 2014 and 2015. The following factors have an effect on the results: stabilization of the economic and political situation, improvement in the major macroeconomic indicators, decline in volatility of national currencies, the enlarged volume of subsidies for small and middle-sized businesses and developed infrastructure. At the same time, 2014 and 2015 were considered crisis years for the whole economy and small and middle-sized businesses in particular. However, the share of positive assessments is relatively larger in the studied publications.

\section{CONCLUSION}

The conducted analysis of the content identified the rise of positive perception of the developments in the business environment in the studied regions.

External support from the regional governments is essential for the further development of SMB and as a result the economy in general. Governmental support can be provided by means of consultancy and methodological assistance as well as financial support and support in the forms of property. Moreover, the support should be objectively considered and aimed at stimulation rather than regulation. For further support of SMB sustainable development, constant monitoring of business attractiveness is essential. The monitoring should be based on the analysis of quantitative indicators, as well as qualitative indicators such as perception 
of business climate of SMB, which was analyzed in this article.

The conducted analysis demonstrates only one third of the possible level of positive assessments in the regions, which indicates the absence of any rise of effectiveness of business attractiveness developments. The statement is supported by the absence of the solutions for the long-standing issues such as:

- $\quad$ excessive preferences towards large businesses in the frames of conducting regional economic policy;

- $\quad$ substantial administrative barriers

- $\quad$ high tax burden on SMB

- limited access to financial resources

- limited number of highly qualified personnel in the sector

The assessment of the solutions effectiveness should be complex and comprise quantitative and qualitative aspects. Proper assessment of business attractiveness will help to reveal major structural drawbacks of regional economies and build a competent governmental policy towards their reduction.

\section{References}

[1] JP. Cabestan, Burkina Faso: Between Taiwan's active public diplomacy and China's business attractiveness, South African journal of international affairs-sajia, pp. 495-519, 2016.

[2] N. Marzieh, V. Thierry, The container transport system: The container transport system: Selection criteria and business attractiveness for North-European ports, Maritime economics \& logistics, pp. 221-245, 2015.

[3] S. Samik, India's urbanization and business attractiveness by 2020 , Cities, pp. 412-416, 2013.

[4] I. Lock, P. Seele, Quantitative content analysis as a method for business ethics research, Business ethics - a European review, 2015, pp. S24-S40.

[5] E. Khan, M. Quaddus, Examining the influence of business environment on socio-economic performance of informal microenterprises Content analysis and partial least square approach, International journal of sociology and social policy, 2015, pp. 273-288.

[6] L. Hadas, A. Stachowiak, P. Cyplik, Decision making model in integrated assessment of business-environment system - a case study, Information technologies in environmental engineering: new trends and challenges, 2011, pp. 419-429.

[7] J. Belas, P. Bartos, J. Habanik, Significant attributes of creation and development of the business environment in the SME segment, 1st International Conference on Finance and Economics (ICFE), 2014, pp. 42-49.

[8] R. Sadyrtdinov, M. Korablev, S. Vladimirova, Assessment of small entrepreneurship impact on the development of Far East Federal District regions of the Russian Federation, International conference on applied economics (icoae), 2015, pp. 557-562.

[9] A. Vorobyev, E. Gilmutdinova, Quality of life as an indicator of governance effectiveness// International Scientific Conferences on Social Sciences and Arts SGEM 2017, (vol. 3), pages 565-573.

[10] I. Glebova, A. Vorobyev. Analysis and Possibilities of Increasing of Labor Potential in the Regions of the Volga Federal District (Russian Federation), vol.6, Mediterranean Journal of Social Sciences, MCSER Publishing, pp. 294-298, 2015. 